By FELIX E. HIRSCH

\title{
The College Librarian as Classroom Teacher ${ }^{1}$
}

\author{
Dr. Hirsch is librarian and professor of \\ history, Bard College.
}

$\mathrm{T}$ HE place of the librarian in the realm of scholarship has been a source of frequent concern to the leaders of our profession. About 16 years ago, Dr. Lucy E. Fay, the wise teacher to whom so many college librarians are deeply indebted, gave a memorable paper on the librarian as scholar. ${ }^{2}$ Citing the examples of three great scholar-librarians of past centuries, Gabriel Naude, Henry Bradshaw and Justin Winsor, she pleaded for strengthening the solid foundations of general scholarship among librarians. To the case histories which she gave might be added two stories of the twentieth century: those of Archibald C. Coolidge, historian and creator of the Widener Library, and Adolf von Harnack, theologian and reformer of the Prussian State Library; both of whom lent by their singular achievements so much splendor to our profession. ${ }^{3}$

These men dedicated themselves to the development of great research libraries. But also the college library may benefit from personalities who combine the qualifications of the academic teacher with those of the skilled librarian. Eight years ago, Branscomb raised the question in his study,

\footnotetext{
1 Paper presented at the Conference of Eastern College Librarians, Columbia University, November 27, 1948 .

2 Fay, Lucy E. "The Librarian as Scholar." School and Society 37:511-516, April 22, 1933.

${ }^{3}$ The most colorful picture of Coolidge is presented in 'Sir Bernard Pares' autobiography $A$ Wandering Student. Syracuse, 1948. About Harnack see my article "The Scholar as Librarian," Library Quarterly 9:299. 320 , July 1939 .
}

Teaching with Books, of whether or not the librarian should also teach. ${ }^{4}$ He pointed then to four examples: the librarians of Pomona and Williams Colleges who were regular members of the departments of political science in their institutions; the librarian of Fisk University (Dr. Carl White, now director of the Columbia University Libraries) who was then also teaching in the department of philosophy; and the librarian of Stephens College who served also as Dean of Instruction. While Branscomb objected to any divided allegiance, he conceded "that where the duties of the library permit, some teaching may be a useful and helpful experience, particularly if it utilizes and keeps alive some special intellectual interest." Branscomb included only a few of the then known significant cases, and in the meantime the number of librarians who are also classroom teachers has increased further. Therefore, it may be justifiable to assess their contribution to our professional work today more in detail than Branscomb cared to do in 1940 .

\section{What Type of Institutions?}

In what type of institutions are librarians serving as classroom teachers? Very few only are holding such dual positions at large institutions. Library administration in a university or a land-grant college or a huge municipal college has become so complex and so energy-consuming a task that only

\footnotetext{
4 Branscomb, Harvie. Teaching with Books. Chicago, A.L.A., 1940. All quotations below are taken from pages 99-100.
} 
very exceptional personalities could assume the additional burden of giving regular courses in some major subject of the curriculum. The situation is more favorable in the smaller and medium-sized colleges, but at least one of the experts consulted, Alexander Laing of Dartmouth, believes that a combination of functions is feasible also in the larger liberal arts college library. Of course, most of us are sighing heavily about unending professional obligations of one kind or another. But it still seems possible to take over certain teaching responsibilities, if we delegate some of our library tasks to competent associates. This has been proved at a fair number of institutions in various parts of the country.

For my statement I do not rely only on my own experience at Bard College over a dozen years, but I have had also the benefit of very extensive and frank comments from Dr. Evelyn Steel Little, librarian, professor of comparative literature and dean of the faculty at Mills College; Dr. Dean P. Lockwood, librarian emeritus and professor of Latin at Haverford College (whose excellent library was built up over a period of seventy years by two outstanding teacherlibrarians, Dr. Lockwood himself and his predecessor Allen Thomas); furthermore from Dr. Robert W. McEwen, former librarian and professor of religion and philosophy at Carleton College, former president of Blackburn and, since February 1949, president of Hamilton College; and Dr. B. Lamar Johnson, librarian and dean of instruction at Stephens College, the only junior college in this group.

Other interesting combinations about which information was received are the following. Dr. Philip M. Benjamin serves as librarian and professor of English literature at Allegheny College; he teaches, e.g., courses on Shakespeare and on the modern novel which are helpful also from the library angle. Newton F. McKeon is librarian and professor of English at Amherst College; while he is at the moment too busy in the library and on leave from his teaching duties, he has carried a considerable instructional load at times and also served one term as acting dean. Alexander Laing at Dartmouth combines his job as assistant librarian with heavy classroom obligations; he gives courses on the Great Issues and the humanities. John H. Berthel, librarian of Columbia College, participated in teaching the course on contemporary civilization for a number of years. Edward G. Hartmann has recently been appointed director of libraries and assistant professor of history at Suffolk University. All of them essentially agree with Mrs. Little who wrote,me: "Like you, I believe in the usefulness of combined administrative and teaching functions for the college librarian, in spite of the danger of killing off the individual."

\section{Thoughts of a Faculty Member}

Before I describe more in detail what the teaching librarians themselves think about their opportunities and achievements, I wish to present the opinion of an unbiased observer. I asked Ruth Gillard, a graduate of Mills College, a former assistant professor of sociology at her alma mater, who is serving now in the same capacity at Bard, to give me from her full knowledge especially of Mrs. Little's work, a frank appraisal of the teaching librarians from the point of view of a sociologist. She believes that "when the librarian is a teaching member of the faculty, his colleagues know that he has the same approach to the use of the library that they have. They know that lists of reserve books receive attention, not simply as a part of library procedure, but as essential working materials needed by students. They know that requests for 
magazines will be viewed not just through the jaundiced eye of the budget or the collector's eye for possessing imposing scholarly collections, but again from the angle of a practicing fellow-teacher who is acquainted at first hand with the education of students." Miss Gillard goes on to state that "the teacher-librarian understands the book needs of the faculty not only from their point of view, but also from the students' who approach him as a teacher in their requests for assistance." Of Mrs. Little in particular she says that "my working materials were increased by a person aware of my teaching needs. We met in the everyday course of events; the problem of getting books for the library was not set off in a niche to be attended to at an appointed time in an appointed place: it became part of the discussion of teaching in general."

Miss Gillard concludes her reflections on the libraries at Mills and Bard: "All in all, it seems to me that the library becomes a more integral part of the teaching situation when it is directed by a person who is himself a teacher. His experience, his relationship with other teachers, with educational materials and situations, with students, cannot help but have a positive effect upon the library."

\section{Knowing the "Consumer"}

Miss Gillard's observations contain many points to which the teaching librarians themselves would heartily agree. First, there is the personal element. Mrs. Little, for instance, feels that "one of the great advantages of the classroom teaching is that it gives a better appreciation of the library needs both of student and faculty. One sees the problem from the other side of the fence, and this experience is a very wholesome brake on restrictive regulations." Any teaching librarian will indeed try to operate with a minimum of rules. He will put the justifiable claims of the individual reader above most other considerations, for he can well visualize the adverse effect that inflexible rigidity may have on the enthusiasm and the accomplishment of a young student. In many ways, the intimate contact with students which the librarian may gain from teaching is his highest reward. Working daily in classes and conferences with young people of varying backgrounds and abilities gives the librarian a better appreciation of the "consumer's" point of view.

May I speak here from my own experience. Due to the increasing popularity of history as an academic subject, I have this term one fifth of our student body in my courses and tutorials. They freely consult me not only about their readings in history, but also in other fields. It is hard to say where the teaching ends and the library work begins. By trying to stimulate this one fifth to make the fullest and most intelligent use of the library resources, I am able to exert a fairly strong influence on a large sector of our reading community. Most of the students, whom I had in my courses during the preceding years, also have remained good friends of the library, and they feel free to drop in my office informally for continued advice. As the years go by, I place less and less stock in drawing undergraduates by complicated displays and other artificial means into the library building, but trust more in the effectiveness of this friendly guidance.

\section{Relations with the Faculty}

As to the faculty, the librarian who also teaches can appreciate the needs of his fellow teachers more easily than the librarian who never had the classroom experience. The teaching librarian will have more sympathy with their book requests and their personal research interests. On the other hand, the fact that he has faced 
the same instructional problems as other faculty members do, gives the librarian more standing in the academic community. President McEwen is certainly correct in saying ${ }^{5}$ that "any complete acceptance of college librarians as full colleagues must await proof that the librarians are genuine participants" in the shared interests of the faculty in teaching and research. While the teaching librarian is unendingly learning in his instructional contacts with the faculty, he has at the same time a wonderful opportunity to do a public relations job for the library. Seemingly by accident, he talks with his faculty colleagues about library problems, be it at divisional or departmental meetings, in various committees to which he is elected because of his academic standing, or at gatherings of the whole faculty. His being also a teacher gives him many additional occasions to interpret the library to the faculty. Therefore, if local conditions permit such a revolutionary move, he may be able to dispense with having a separate library committee, because his faculty colleagues will have inherent confidence in his policy and he in turn will shape his actions to be most beneficial to their academic work and will solicit their advice frequently, but informally.

The classroom experience is also an asset to the librarian in developing the library collections. The teaching librarian, if he is a broadminded scholar and avoids partiality for his own academic subject as far as humanly possible, is well-suited to build up the book collection as a strong tool of the educational program. With President McEwen he will be always aware of the truth, that the college library has "properly no objectives of its own, rather it serves the objectives of the institution of which it is a part. Its book collection ought to reflect

5 McEwen, Robert W. "The Status of College Librarians." College and Research Libraries 3:256-26r, June 1942 . the institution's academic and curricular objectives." These objectives and the particular methods used in reaching them are familiar to the teaching librarian not just from reading the college catalog and from theoretical discussions, but from his daily working experience. After some years of teaching, he will have built up an almost instinctive knowledge of what kinds of materials faculty members and students in his particular institution may need. As a rule, he will avoid the costly purchase of inconsequential niceties and will center his efforts on the acquisition of those materials for which he can envision future users at the moment when he sends out his orders.

The teaching librarian will give strong support to those faculty members who know how to make full use of the library resources. He will tactfully fill the gaps left by those of his teaching colleagues who are not quite aware of the general literature in their fields while they are excellent experts on some specific subjects. Occasionally, he may buy some books needed primarily for the research purposes of an instructor, knowing full well that eventually a sizeable number of students will benefit from the results of his research and that perhaps some juniors or seniors may be tempted later to use them to some extent. The addition of new magazine subscriptions and the building up of periodical sets will also be scrutinized with the teaching aims of the institution foremost in the librarian's mind. He will go out of his way to help seniors engaged in preparing a thesis or project on some highly specialized topic, and he will know pretty well what books ought to be bought to kindle in freshmen the tender flame of their desire for learning.

\section{The Librarian as Dean}

A word may be said here also about the relations between the teaching librarian and 
the college administration. It seems to me that he is in a stronger position than other librarians when it comes to dealings with his authorities. College presidents may be more inclined to trust his judgment and to accept his claims (usually claims for more money), if they know that he enjoys the full confidence of his teaching colleagues and speaks also from classroom experience.

In two institutions, Mills and Stephens, librarians have risen to the rank of academic deans. I am not sure that this combination would be generally desirable, for the librarian should aim in principle at being a close colleague, but not the superior of the teaching faculty. However, in these two exceptional cases, Mills and Stephens, the combination has proved to be highly effective. Mrs. Little believes that her present position as dean of the faculty is of benefit to the library although it absorbs the greater part of her time. "The gain," she writes, "is perhaps intangible, but the very fact that I am in charge of the instructional program puts the library and its needs at the forefront of that problem." It also adds to the prestige of the library and its staff and gives her a chance to see to it that the library is never overlooked in general college policies or in budgetary matters. Dr. B. Lamar Johnson feels likewise, that this "dual position of dean of instruction and librarian has been of inestimable value in our efforts to make the library an integral part of the teaching." From time to time, he teaches also regular college courses, since he believes that for both of his jobs he needs the contact with classroom problems and situations. At Stephens other library staff members, too, are teaching courses in academic subjects in which they are appropriately equipped. ${ }^{6}$

6 See Johnson, B. Lamar and Lindstrom, Eloise, eds. The Librarian and the Teacher in General Education: a Report on Library.Instructional Activities at Stephens College. Chicago, A.L.A., 1948.

\section{Conditions of Success}

The combination of teaching with library administration will be successful only in those institutions which meet a number of conditions. First of all, the appointment should not be made primarily to save money. ${ }^{7}$ If the librarian is to teach, he needs at his side an assistant or associate librarian who is able to supervise much of the current library routine independently in the right spirit. The librarians of Mills, Haverford and Bard agree on the paramount importance of this point. Dr. Lockwood states the case clearly: "If a far-seeing scholar has charge of a department of instruction in the college and, at the same time, is in command of the library, he must have a technical assistant of imagination and creative ability. It is possible that one man might do everything, but not probable. The essential point is that a person of proven ability in pure scholarship be in the commanding position and run the show, rather than the other way around."

Secondly, care should be taken that the teaching load for the librarian does not become excessive. Dr. Lockwood at Haverford carried for 25 years a full teaching schedule of 9 to 15 hours a week in addition to his library job. He says in retrospect: "In the beginning it was not so bad, but as the years went on, it became very unsatisfactory." From my own experience I am inclined to agree with him. Through nobody's fault, my own instructional obligations have constantly grown till they have frequently exceeded those of full-time teachers at Bard, but I feel that I am not

\footnotetext{
7 Raymond M. Hughes, former president of Iowa State College, says, however, in his Manual for Trustees of Colleges and Universities, second edition, Ames 1945, p. 109: "The librarian in a college, if fully com1945, p. 109: "The librarian in a college, if fully com-
petent, should be of the rank of a full professor. petent, should be of the rank of a full professor.
Usually, if it is impossible to pay the librarian a full professor's salary, it is wise either to arrange to se. cure a librarian who can teach part time, or to appoint cure a librarian who can teach part time, or to appoint as librarian a full professor who does teach but who
would be most able properly to supervise the library, would be most able properly to supervise the 1,
and give him trained librarians as assistants."
} 
as robust as Dr. Lockwood and will have to cut down on them before long. At one salary, nobody should be obliged to hold two full-time jobs, but some kind of a genuine $50-50$ proposition should be developed, in the best interest of the institution. The teaching librarian has a right to claim some leisure for the pursuit of his scholarly research and writing interests. The library will inevitably profit from such endeavors. "Active participation in research and publication," says Dr. Lockwood, "gives him a feeling for books and an ability in estimating their worth that can be acquired in no other way. He can set standards for all departments."

\section{What Kind of Training?}

Thirdly, not everybody who holds a Ph.D. degree and has had some teaching experience, will make an effective teacherlibrarian. A narrow specialist who wrote a thorough thesis on a not very significant subject, is not the person to look for, nor should we forget Branscomb's warning: "It is obvious that this is not the place for the broken-down or ineffective teacher." Only an active scholar with a wide view of higher learning, a man or a woman who combines enthusiasm for teaching with a full understanding of library administration, will meet the need. You may say that it is hard to find people who have all these qualifications. This may be true today, but should we, therefore, give up hope for tomorrow? Instead of taking a defeatist attitude, we should make every possible effort to attract this type of scholarly person to our profession. The revolution in the curricula of the leading library schools may be of immeasurable help in this respect.

A master's degree in library science, as it is now offered, plus graduate training in a major academic subject, will be the best way in which to prepare for the dual career of a teaching librarian. It is not decisive that the graduate study has been pursued up to the acquisition of the Ph.D. In many cases, a master's degree from a good graduate school will suffice, certainly for the beginning. Emphasis should be, to quote once more from President McEwen's letter, on securing for college library staffs more "men and women who are themselves educators in some real sense, who are in college library work not because they are librarians, but because it is the library part of the college program which particularly appeals to them."

\section{Staff Members May Also Teach}

This description would not be limited necessarily to head librarians, but could and should fit also many assistant librarians, department heads, reference assistants, etc. There would be no harm done if various qualified professional members of the library staff would engage regularly in some formal teaching. How much richer would their career be, if staff members could develop a variety of talents instead of being tied to one line of library work which inevitably contains so much routine drugery. This would probably result in fuller human satisfaction, better salaries, and certainly in a higher social rating of the library staff in the college community. The last point is not unimportant. We talk so much about the faculty status for the professional members of the library staff. Of course, this faculty status is desirable. But we will be entitled to claim it only for those people who have faculty qualities. It is not enough to be a fine specialist in some line of library work. If staff members want to participate intelligently in the councils of the faculty, they have to have the same scholarly foundation and the same educational outlook as the rest of the faculty is

(Continued on page 128) 
efforts to dragoon the faculty into a more creative view of "teaching with books." What is needed is full responsibility on one of these sides or the other. Knowing teachers, and having tried off and on to be one, I think the responsibility had better be on the librarian's side.

\section{Responsibility for Use}

How is this to be done? The first move is to build a philosophy of librarianship which accepts full responsibility for creating a level of use adequate to justify all the loving care that goes into acquisition and maintenance. This "third force," to swipe a political image, should not be the marginal "maybe" of our endeavor-but it will continue to be the marginal "maybe" until librarians have made it clear to their presidents and trustees that they are willing to accept full responsibility for the over-all expenditure which the building, maintaining, and use of book stock imply. If we continue to feel entirely responsible for behind-the-scenes technology, and less responsible about other services, we shall evade a problem that we ourselves, in our technological pride, create. We shall deserve to be called "mere" technicians.

A librarian aware of his responsibility, and knowing what was expected of him, could take a budget of any size and apportion it between the three factors: acquisi- tion, maintenance, and use. He would not slight the third. If his book funds automatically demanded more staff than a proportional budget would allow, he could change his buying habits in accordance with local needs-buying perhaps more rarities, or more duplicates-whatever would most intelligently increase the utility of all his resources and lower behind-the-scenes costs.

As matters now are developing, the academic library is tending toward the sad, hypothetical situation of an airline which spends half of its resources for excellent planes, and the other half for superlative airports and upkeep facilities, and has nothing left to pay the pilots.

The program for which I have been arguing calls for a basic reorientation of our concept of the academic librarian. Surely we should not underrate the magnificent work of those who have raised librarianship from a triumph of memory over muddle to a conceptual technology of good order. Technologists become "mere," not in honoring their science to the full, but in forgetting that at best it is a perfect means toward a wise end. All the perfection of means can be futile, or evil, if the end is ill-perceived. Wisdom of final purpose should not be sacrificed to mere technology, when the two conflict. It is my hope that very few of you are content to regard yourselves as "mere."

\section{The College Librarian as Classroom Teacher}

\section{(Continued from page 118 )}

expected to have. Any claim for faculty status which is only a craving for privileges and is not based on such equality in the essential qualifications, is unreasonable.

In conclusion, I would like to say that I do not share Harvie Branscomb's fear, that a potentially excellent librarian might dissipate his interests and energies by as- suming larger teaching functions. I believe that the cases of Haverford, Mills, Carleton, Allegheny, Stephens, various others, and, I hope, also Bard, demonstrate that both the library and the academic community gain when the librarian becomes a part of the teaching faculty, bridging the gap between the library and classroom. 